\title{
Islamic Work Ethic and Employee Engagement, Variable to Improve Employee Job Satisfaction
}

\author{
Andhika Mochamad Siddiq ${ }^{1}$, Hady Siti Hadjiah ${ }^{2}$ \\ Program Studi Manajemen, Sekolah Pasca Sarjana, Universitas Pendidikan Indonesia, Bandung, Indonesia ${ }^{1}$ \\ Program Studi Pendidikan Manajemen perkantoran, FPEB. Universitas Pendidikan Indonesia, Bandung, Indonesia ${ }^{2}$
}

\begin{abstract}
This study wants to reveal how much influence from Islamic work ethic (IWE) and Employee Enagagement on employee job satisfaction. The study also wants to verify the two independent can be used to improve employee job satisfaction This research is located at Amanda Brownies Company, where Amanda Brownies Company whose employees are moeslem. The method used in this research are descriptive and verificative research method with simple random sampling technique. The population in this study were employees of the Amanda Brownies Company in Bandung City totaling 428 with a sample of 210 employees. The population was divided into factories, outlets and offices.The data analysis technique used is multiple linear regression analysis with SPSS 25.0 computer software as a tool to analyze the data. The results of the study show there is a positive effect of Islamic work ethics on employee job satisfaction by $23.9 \%$. There is also a positive effect of Employee engagement on employee job satisfaction by $29,1 \%$. Finally, with a simultaneous test, it was found that there were influences from the two independent variables to employee job satisfaction with $31 \%$ the percentage effect. Thus it was concluded that islamic work ethic and employee engagement can be used to improve the employee job satisfaction. There are limitations in this study, namely respondents who are not balanced between factory employees and office employees so that the results of the study show a low influence. The other limitation is that the research conducted to only reveal the influence, the other researcher need to focus on how to improve the two independent variable.
\end{abstract}

Keywords: islamic work ethic; employee engagement; employee job satisfaction; employee

Article history. Received January, 2019. Revised March, 2019. Accepted June, 2019

Corresponding author. ${ }^{1}$ andhika.mochamad@upi.edu, ${ }^{2}$ hady@upi.edu

How to cite article. Siddiq, A. M., \& Hadjiah, H. S. (2019). Islamic Work Ethic and Employee Engagement, Variable to Improve Employee Job Satisfaction. The International Journal of Business Review (The Jobs Review), 2(1), 9-18. https://doi.org/https://doi.org/10.17509/tjr.v2i1.17771

\section{INTRODUCTION}

Satisfaction is something that all humans will strive to achieve. Satisfaction is a comparison between what is expected and what is obtained. To achieve satisfaction, the reality obtained must be greater than what is expected for people to achieve satisfaction. This is common and occurs in various aspects. One of the sciences that addresses satisfaction is the science of human resource management (HRM) where human resorces management discusses the job satisfaction of an employee.

From the definition above, job satisfaction is a psychological condition in which a person gets the job comfortably. Job satisfaction is a general attitude towards one's work as a difference between the rewards received by workers and the amount of rewards that are believed to be accepted (Robbins \& Judge, 2015). Satisfaction is an effectiveness or emotional response to various aspects of work (Robert \& Kinicki, 2001). Job satisfaction is shown by various things, one of which is commitment to the company. When an employee continues to be and works for the company, we can assume that the employee is satisfied with his/ her job. Some studies suggest that job satisfaction is influenced by Islamic work 
ethics (Marri, M. Y. K. , Sadozai, A. M. , Zaman, H. M. F. , Yousufzai, M. I. , \& Ramay, 2012; Mohamed, N. , Abdul Karim, N. S. , \& Hussein, 2010).

Islamic Work Ethic (IWE) is not a new discussion. In 1988 a researcher named Abbas Ali began a discussion about IWE by using the Al-Quran and the Sunnah as guidelines to explain these variables. Al-Quran and Sunnah as one of the holy scriptures and have never experienced revisions make a strong reason that IWE is a way to work well. Many studies have been conducted with regard to IWE, other studies suggest that IWE has a positive effect on job satisfaction (Balkis, Saadah, \& Abbas, 2017). Other studies suggest that IWE also has a positive effect on employee engagement (Tufail, Ahmad, Ramayah, Jan, \& Shah, 2016) and one study stated that IWE affects job satisfaction and organizational commitment (Shafique, Haseeb, Ahmad, Khurshid, \& Ahmad, 2015). With the various studies above, it explicitly explains that IWE is one of the interesting topics that need to be applied to employees who are Moeslems.

At the beginning of 2019, precisely in January the HRD CV. Amanda announced a new policy regarding working hours. Working hours which initially start at 08.00 and end at 16.00 are changed to 08.30 and end at 16:30. This is done because there are many employees who are late for work. Because of that HRD takes this policy. From this phenomenon, it can be seen that there is a problem that HRD Amanda Company is trying to overcome. This problem is the indiscipline of employees to enter on time. Discipline is the output or the result of one indicator of job satisfaction, namely responsibility. Employees are not responsible for attendance problems indicating that employee job satisfaction at CV. Amanda is in a low level. From this phenomenon, it was also found that employees lack enthusiasm or are eager to work. The enthusiasm or passion of work is a characteristic of employees who are satisfied so that the condition that Amanda Company employees are dissatisfied with their work. This needs to be handle as soon as possible in various ways, one of which is to change the working hours as what was done by the HRD Amanda. However, the policy will not be optimal if there is no continuous step to overcome the problem.

Employee job satisfaction can be improved by increasing Islamic work ethics. All employees of Amanda Brownies company are Muslim, so it is easy to apply Islamic values to their employees. Apart from Islamic values, Islamic work ethic will also be easy to be accepted by all employees because they are moeslems and should have Islamic work ethic in each of them. One function of Islamic work ethic is to guide morals in taking every decision and action while working of a moeslems.

Another way to increase employee job satisfaction is to increase employee engagement. Employee engagement is a variable that can affect job satisfaction in accordance with one study that shows that employee engagement positively influences employee job satisfactio (Jain, 2018; Jaiswal, Pathak, \& Kumari, 2017). This shows that employee engagement is another way to increase employee job satisfaction.

The Employee Job Satisfaction needs to be improved to support various things, one of which is the performance of both the company and employees. One way that can be done is to increase the application of Islamic work ethics by the management of Amanda's company in the form of work rules or S.O.P. This will be easier because all employees of the Amanda company are moeslems. This can directly increase employee job satisfaction, so that if employee job satisfaction is high, it will have an impact on employee performance and 
employee productivity. Another wat to improve the employee job satisfaction is to increase the employee engagement so the employee job satisfaction will be increase as well.

\section{Islamic Work Ethic}

Islamic Work Ethic (IWE) is not a new discussion. In 1988 a researcher named Abbas Ali began a discussion about IWE by using the Al-Quran and the Sunnah as guidelines to explain these variables. Al-Quran and Sunnah as one of the holy scriptures and have never experienced revisions make a strong reason that IWE is a way to work well. Many studies have been conducted with regard to IWE, other studies suggest that IWE has a positive effect on job satisfaction (Balkis, Saadah, \& Abbas, 2017). Other studies suggest that IWE also has a positive effect on employee engagement (Tufail et al., 2016) and one study stated that IWE affects job satisfaction and organizational commitment (Shafique, Haseeb, Ahmad, Khurshid, \& Ahmad, 2015). With the various studies above, it explicitly explains that IWE is one of the interesting topics that need to be applied to employees who are Moeslems.

In general, research on IWE is fragmented on two impacts, namely on individuals and organizations (Hendryadi, 2018). These variables are job satisfaction, commitment, innovation, ksb, justice, ocb, organizational performance, turnover, job involvement and so forth. Islamic work ethics in the 2010-2017 research period is more associated with individual attitudes and behavioral factors.

Other studies specifically discuss the relationship about Islamic work ethics to employee job satisfaction. Some studies show that IWE affects job satisfaction (Balkis, Saadah, \& Abbas, 2017; Marri, Sadozai, Zaman, \& Ramay, 2012; Mohamed, Karim, \& Hussein, 2010). The results of the study show that there is a relationship between Islamic Work Ethics and Employee Job Satisfaction.

\section{Employee Engagement}

Employee Engagement is one of the concepts developed from positive psychology and positive organizational behavior. Kahn described the theory of relationships with involvement that occurs closely physically, cognitively and emotionally between a person and his role in a job, which is then referred to as an Employee Engagement (Kahn, 1990). In line with the definition above, Federman views employee engagement as a level where a person behaves and how long he will stay with his position (Federman, 2009).

Employee Engagement is a condition in which employees are excited, passionate, energetic, and committed to his work (Maylett \& Warner, 2014). Schaufeli and Bakker, Rothbard (in Saks, 2006) define Engagement as further psychological involvement involving two important components, namely attention and absorption. Attention refers to the availability of cognitive and total time used by an employee in thinking and carrying out his role, while Absorption is to interpret roles and refers to the intensity of an employee's focus on roles in the organization.

Schaufeli and Bakker mention three aspects in the Employee Engagement Schaufeli \& Bakker (in Salmabadi, Fatehi, Mortezaheidari, \& Mousavikia, 2015). The first is vigor, the second is dedication, and the last is absorption.

Some research results show that employee engagement is a variable that influences employee job satisfaction (Jain, 2018; Jaiswal et al., 2017). Based on the results of these studies, it can be concluded that there is a relationship between employee engagement and employee job satisfaction.

11 | The International Journal of Business Review (The Jobs Review) | Vol.2 | No.1 | 2019 


\section{Employee Job Satisfatction}

According to Kreitner and Kinicki (2001) job satisfaction is an effectiveness or emotional response to various aspects of work. Davis and Newstrom (1985) (in Singhal, Tiwari, and Rajput, 2016) describe job satisfaction as a set of employee feelings about whether or not their work is pleasant. According to Robbins and judge (2015) job satisfaction is a general attitude towards someone's work that shows the difference between the number of awards received by workers and the amount they believe they should receive.

Job satisfaction is an affective or emotional response to various aspects or aspects of one's work so that job satisfaction is not a single concept. A person can be relatively satisfied with one aspect of work and not satisfied with one or more other aspects. Job Satisfaction is a (positive) attitude towards the workforce, which arises based on an assessment of the work situation. The assessment can be carried out on one of its jobs, the assessment is done as a sense of respect in achieving one of the important values in the work. Satisfied employees prefer their working situation.

Employee job satisfaction is an important variable to study. This is due to the influence of job satisfaction on other variables such as performance (Khan, Nawaz, Aleem, \& Hamed, 2012; Ndulue \& Ekechukwu, 2016) and productivity (Embuldeniya, 2017). The amount of influence of job satisfaction makes this variable examined as a dependent variable.

\section{Hypothesis}

Organizational behavior is a study of what people do in an organization and how their behavior affects organizational performance (Robbins \& Judge, 2015). Gibson (2012) explains that there are 3 objects in the concept of organizational behavior, namely individuals, groups and organizations. The behavior of an individual is influenced by various aspects. One aspect that affects this individual's behavior is the Employee Job Satisfaction. Employee Job Satisfaction is an effectiveness or emotional response to various aspects of work (Robert \& Kinicki, 2001). From this understanding that effectiveness or emotional response is influenced by various aspects of work.

Some aspects of work that affect the Employee Job Satisfaction are Employee Engagement and Islamic Work Ethics. One study stated that Employee Engagement affects Employee Job Satisfaction (Jaiswal et al., 2017) and other journals mention that Islamic Work Ethic affects Employee Job Satisfaction (Balkis et al., 2017). Based on that, the writer will analyze the effect of Islamic Work Ethics on Employee Job Satisfaction, Employee engagement and its impact on Employee Job Satisfaction.

\section{RESEARCH METHOD}

The method in this study is descriptive and verificative. This study tries to describe the condition of each variable and verify the hypothesis proposed. The population in this study were employees of the Amanda Brownies Company in Bandung City totaling 428. The population was divided into factories, outlets and offices. The number of samples was 210 randomly selected. After all the questionnaires that have previously been tested valid and reliable, process and analyze questionnaire data with SPSS 25 tools. Data analysis using multiple linear regression analysis to determine the magnitude of the influence of each independent variable to the dependent variable. 


\section{RESULTS AND DISCUSSION}

From the 210 questionnaires distributed, the researchers got a general description of respondents in this study. First, $46 \%$ of respondents were male and $54 \%$ of respondents were women. Secondly in terms of education $1 \%$ graduated from junior high school, $23 \%$ graduated from high school, 23\% graduated from diploma, and 53\% graduated from bachelor degrees. Third, $54 \%$ of respondents have only worked 1 to 5 years, $35 \%$ of respondents have worked 6 to 10 years, $3 \%$ of respondents have worked more than 10 years and $3 \%$ of respondents have worked less than 1 year.

Table 1. Questionnaire Recapitulation Results

\begin{tabular}{lcl}
\hline Variable & Percentage & Information \\
\hline Islamic Work Ethic & 76,88 & Effective \\
Employee Engagement & 78,48 & Strong \\
Employee Job Satisfaction & 80,33 & Satisfied \\
\hline
\end{tabular}

From table. 1 we can see the condition on each variable in this research. The result show the Islamic work ethics, employee engagement and employee job satisfaction employees are quite diverse. The level of implementation of Islamic work ethic is in the effective category. Employee engagement is in the strong category. employee job satisfaction is included in the interpretation of values with a very satisfied category.

The employee job satisfaction level is determined by the effectiveness of the application of Islamic work ethics and the strong employee engagement that occurs. The description of job satisfaction can be seen from several characteristics, namely comfort during work, pleasure and love of work, happiness during work and responsibility.

Table 2. The R Square Result

\begin{tabular}{lcc}
\hline \multicolumn{1}{c}{ Variable } & R Square & Percentage Effect \\
\hline Islamic Work Ethic & 0,239 & $23,9 \%$ \\
Employee Engagement & 0,291 & $29,1 \%$ \\
\hline
\end{tabular}

Based on the results of the R Square using SPSS 25 software in the table 2, the results show that Islamic work ethic has a significant influence on employee job satisfaction. The influence of Islamic work ethic $\left(\mathrm{X}_{1}\right)$ on employee job satisfaction $(\mathrm{Y})$ is $23.9 \%$. Employee engagement $\left(\mathrm{X}_{2}\right)$ has a significant influence on employee job satisfaction with an influence of $29.1 \%$. 
Table 3. The Coefficients Result

\begin{tabular}{|c|c|c|c|c|c|}
\hline \multirow[t]{2}{*}{ Model } & \multicolumn{2}{|c|}{$\begin{array}{l}\text { Unstandardized } \\
\text { Coefficients }\end{array}$} & \multirow{2}{*}{$\begin{array}{c}\text { Standardized } \\
\text { Coefficients } \\
\text { Beta }\end{array}$} & \multirow[t]{2}{*}{$\mathrm{t}$} & \multirow[t]{2}{*}{ Sig. } \\
\hline & B & Std. Error & & & \\
\hline 1 (Constant) & 5,316 & 1,152 & & 4,614 & 000 \\
\hline Islamic Work Ethic &, 062 & ,026 & ,201 & 2,362 & ,019 \\
\hline Employee & ,294 &, 064 & ,392 & 4,613 & ,000 \\
\hline Engagement & & & & & \\
\hline
\end{tabular}

From the simultaneous testing of the two independent variables on the table 3, the result is that the regression equation coefficient is $\mathrm{Y}=5.316+0.062 \mathrm{X}_{1}+0.294 \mathrm{X}_{2}$. The test results show a significance value of 0.000 , so it is seen from the significant value that is lower than the degree of alpha error that is 0.05 . Then ho's decision was rejected and accepted ha. Islamic work ethic and employee engagement have a significant influence on employee job satisfaction both partially and simultaneously.

The results of the research obtained have similarities with several other research results such as Balkis et al., (2017), Marri et al., (2012) and Mohamed et al.(2010). In which in their research the islamic work ethic has a positive and significant effect. Also, the results of the research obtained have similarities with several other research results such as Jain (2018); Jaiswal et al., (2017). These results indicate that indeed Islamic work ethics can be used to improve employee job satisfaction. With the increase of Islamic work ethics, employee job satisfaction will increase as well. These results also show that employee engagement can be used to improve employee job satisfaction. With increasing employee engagement, employee job satisfaction will increase as well.

From the results of testing the hypothesis, it is proven that Islamic work ethic and employee engagement can control employee job satisfaction variables. This has an impact on HR managers who can implement Islamic work ethics by integrating it into the Standard Operational Procedure (SOP). With this, managers can increase employee job satifaction which in turn will have an impact on work performance and productivity.

The next thing is managers cannot close their eyes to the level of employee engagement. Managers need to take steps to increase employee engagement such as optimizing work facilities and a conducive work environment that will increase employee engagement. So that if done simultaneously the effects on employee job satisfaction will be significant.

The results of the study show that the influence of the two independent variables is not great. This may be influenced by the knowledge of HRD and employees regarding Islamic work ethics itself. Because basically an action without knowledge results will not be effective, whereas if before doing an act of the HRD and all employees know about the concept of Islamic work ethic then the application will certainly be more effective which will later affect employee job satisfaction. 


\section{CONCLUSION}

From the results of the study it was found that Islamic work ethics are at an effective level, employee engagement is at a strong level and employees are satisfied with their work. From the conditions of the two variables, the effect on employee job satisfaction can be seen. Separately, Islamic work ethics and employee engagement have an effect on employee job satisfaction with each influence percentage $23.9 \%$ and $21.9 \%$. Simultaneously, it is evidently proven that the two independent variables influence employee job satisfaction with a percentage effect of $31 \%$.

There are limitations in this study. First, the research conducted does not use the cluster sampling method so that employees are not categorized. This has an effect on the results of low influence because generally factory employees do not know what Islamic work ethic or employee engagement is so that they do not care too much about the conditions of Islamic work ethics and employee engagament. Second, this research only describes and verifies the influence of Islamic work ethics and employee engagement on employee job satisfaction. There needs to be further research on how to improve Islamic work ethics and employee engagement to improve employee job satisfaction.

\section{REFERENCES}

Abeng, T. (1997). Business Ethics in Islamic Context : Perspectives of a Muslim Business. Business Ethics Quarterly, 7(3), 47-54.

Al-Modaf, O. A. (2005). Islamic work ethic code: a conceptual study. Umm Al-Qura University Educational, Social Sciences and Humanities, 17(3), 9-28.

Ali, A. (1988). Scaling an Islamic Work Ethic. The Journal of Social Psychology, 128(5), 575-583. https://doi.org/10.1080/00224545.1988.9922911

Ali, A. (2005). Islamic perspective on management and organization. Cheltenham: Edward Elgar.

Ali, A. J. (1992). The Islamic Work Ethic in Arabia. The Journal of Psychology: Interdisciplinary and Applied, 126(5), 507-519. https://doi.org/10.1080/00223980.1992.10543384

Ali, A. J., \& Al-kazemi, A. A. (2014). Islamic work ethic in Kuwait work ethic. Cross Cultural Management: An International Journal, 14(2), 93-104. https://doi.org/10.1108/13527600710745714

Ali, A. J., \& Al-Owaihan, A. (2008). Islamic work ethic : a critical review. Cross Cultural Management: An International Journal, 15(J1), 5-19. https://doi.org/10.1108/13527600810848791

Anoraga, \& Widiyanti. (2011). Psikologi dalam Perusahaan. Jakarta: Rineka Cipta.

Arikunto, S. (2016). Prosedur Penelitian Suatu Pendekatan Praktik. Jakarta: Rineka Cipta.

As'ad, M. (2000). Psikologi Industri. Yogyakarta: Liberty.

Balkis, Q., Saadah, N., \& Abbas, R. (2017). The Effect of Islamic Work Ethics on Job Satisfaction in Organization; a Study in Sekolah Rendah Islam Indera Mahkota (Sri Abim), Kuantan. Journal of Global Business and Social Entrepreneurship (GBSE), 1(3), 46-61.

Davis, K., \& Newstrom, J. W. (1985). Perilaku Dalam Organisasi. Jakarta: Erlangga. 
Embuldeniya, A. (2017). The Impact of Employee Job Satisfaction On Employee Productivity In Apparel Industry of Sri Lanka. EPRA International Journal of Multidisciplinary Research (IJMR), 3(12), 14-23.

Federman, B. (2009). Employee Engagement: A Road For Creating Profits, Optimizing Perfomance, And Increasing Loyalty. San Fransisco: Jossey Bass.

Handoko, H. T. (2008). Manajemen Personalia dan Sumber Daya Manusia (II). Yogyakarta: BPFE Yogyakarta.

Hasibuan, M. S. P. (2009). Manajemen Dasar, Pengertian, Dan Masalah. Jakarta: PT Bumi Aksara.

Hendryadi. (2018). Islamic Work Ethics (IWE): Konsep dan Tinjauan Penelitian. Jurnal Riset Manajemen Dan Bisnis (JRMB) Fakultas Ekonomi UNIAT, 3(2), 183-190. Retrieved from http://jrmb.ejournal-feuniat.net/index.php/JRMB.

Jain, R. (2018). Impact of Employee Engagement on Job Satisfaction at Ultratech Cement Limited-HCW. International Journal of Computer \& Mathematical Sciences (IJCMS), 7(3), 45-51.

Jaiswal, G., Pathak, R., \& Kumari, S. (2017). Impact Of Employee Engagement On Job Satisfaction And Motivation. In S. Bhakar, C. Gulati, G. Mathur, \& R. Pathak (Eds.), Global Advancements In HRM Innovation and Practices (1st ed., pp. 66-78). New Delhi: Bharti Publications. Retrieved from https://www.researchgate.net/publication/316662915_Impact_Of_Employee_Engagem ent_On_Job_Satisfaction_And_Motivation

Kahn, W. A. (1990). Psychological Conditions of Personal Engagement and Disengagement at Work. Academy of Management Journal, 33(4), 692-724. https://doi.org/10.5465/256287

Kaplan, R. M., \& Saccuzzo, D. P. (1993). Phsycological Testing principles, application, and issues. California: Brooks/Cole Publishing Company.

Kartono, K. (1994). Pemimpin dan Kepemimpinan. Jakarta: PT Raja Grafindo.

Khan, A. H., Nawaz, M. M., Aleem, M., \& Hamed, W. (2012). Impact of job satisfaction on employee performance: An empirical study of autonomous Medical Institutions of Pakistan. African Journal of Business Management, 6(7), 2697-2705. https://doi.org/10.5897/AJBM11.2222

Khan, K., \& Abbas, M. (2015). Organizational Justice and Job Outcomes : Moderating Role of Islamic Work Ethic. Journal of Business Ethics, 126(2), 235-246. https://doi.org/10.1007/s10551-013-1937-2

Kumar, N., \& Rose, R. C. (2010). Examining the link between Islamic work ethic and innovation capability. Journal of Management Development, 29(1), 79-93. https://doi.org/10.1108/02621711011009081

Luthans, F. (2011). Organizational Behavior: An Evidence-Based Approach. New York: McGraw-Hill.

Macey, W. H., Schneider, B., Barbera, K. ., \& Young, S. A. (2009). Employee Engagement: Tools for Analysis, Practice, and Competitive Advantage. USA: John Wiley \& Sons.

Marri, M. Y. K., Sadozai, A. M., Zaman, H. M. F., \& Ramay, M. I. (2012). The Impact of Islamic Work Ethics (IWEs) on Job Satisfaction (JS) and Organizational Commitment (OC): A Study of Agriculture Sector of Pakistan. International Journal of Business and Behavioral Sciences, 2(12), 32-45.

16 | The International Journal of Business Review (The Jobs Review) | Vol.2 | No.1 | 2019 
Maylett, T., \& Warner, P. (2014). Five Keys to Unlock the Power ofEmployee Engagement. Texas: Decision Wise, Inc.

Mohamed, N., Karim, N. S. A., \& Hussein, R. (2010). Linking Islamic Work Ethics (IWEs) to Computer Use Ethics, Job Satisfaction (JS) and Organizational Commitment (OC) in Malaysia. Journal of Business Systems, Governance and Ethics, 5(1), 13-23. https://doi.org/10.15209/jbsge.v5i1.175

Ndulue, T. I., \& Ekechukwu, H. C. (2016). Impact of Job Satisfaction On Employees Performance: A Study Of Nigerian Breweries PLC Kaduna State Branch, Nigeria. Arabian Journal of Business and Management Review, 5(11), 13-23.

Nurofia, F. (2009). Mengenal Employee Engagement. Maranatha Universuty, 1-16.

Pidarta, M. (1988). Manajemen Pendidikan. Jakarta: PT Bina Aksara.

Ramalu, S. S., \& Rashid, Z. M. (2017). Islamic Work Ethic, Employee Engagement and Organizational Citizenship Behaviour: A Study Among Civil Servants In Malaysia. Journal of Global Business and Social Entrepreneurship (GBSE), 1(2), 43-55.

Riggio, R. E. (2003). Introduction to Industrial/Organizational Psychology. New Jersey: NewJersey Inc.

Rivai, V., \& Sagala, E. J. (2014). Manajemen Sumber Daya Manusia untuk Perusahaan: Dari Teori ke Praktik (3rd ed.). Rajawali Pers.

Robbins, S. P., \& Judge, T. A. (2015). Perilaku Organisasi (16th ed.). Jakarta: Salemba Empat.

Robert, K., \& Kinicki, A. (2001). Organizational Behavior (Fifth). Irwin McGraw-Hill.

Rokhman, W. (2010). The Effect of Islamic Work Ethics (IWE) on Work Outcomes. Electronic Journal of Business Ethics and Organization Studies, 15(1), 21-27. https://doi.org/10.4103/1817-7417.104699

Saks, A. M. (2006). Antecedents and consequences of employee engagement. Journal of Managerial Psychology, 21(7), 600-619. https://doi.org/10.1108/02683940610690169

Salahudin, S. N. bin, Baharuddin, S. S. binti, Abdullah, M. S., \& Osman, A. (2016). The Effect of Islamic Work Ethics on Organizational Commitment. Procedia Economics and Finance, 35(October 2015), 582-590. https://doi.org/10.1016/S2212-5671(16)00071-X

Salmabadi, M., Fatehi, H., Mortezaheidari, \& Mousavikia, A. A. (2015). The role Islamic work ethics in the employee engagement. Journal of Biodiversity and Environmental Sciences (JBES), 6(5), 463-470. Retrieved from http://www.innspub.net/wpcontent/uploads/2015/06/JBES-Vol6No5-p463-470.pdf

Santoso, S. (2018). Konsep Dasar dan Aplikasi SEM dengan AMOS 24. Jakarta: PT Elex Media Komputindo.

Sarwono, J. (2006). Metode Penelitian Kuantitatif \& Kualitatif. Yogyakarta: Graha Ilmu.

Schaufeli, W. B., \& Bakker, A. B. (2004). Job demands, job resources, and their relationship with burnout and engagement: A multi-sample study. Journal of Organizational Behavior, 25(3), 293-315. https://doi.org/10.1002/job.248

Shafique, M. N., Haseeb, M., Ahmad, N., Khurshid, M., \& Ahmad, H. (2015). The Influence of Islamic Work Ethics on Job Satisfaction and Organization Commitment. Journal of Marketing and Consumer Research Journal, 14(1999), 23-29.

Singhal, M., Tiwari, S., \& Rajput, S. (2016). Job Satisfaction \& Employee Loyalty: a Study of Academicians. Gwailor. Retrieved from https://www.researchgate.net/publication/303724537 
Sugiyono. (2016). Metode Penelitian Kuantitatif Kualitataif dan Kombinasi (Mixed Methods). Bandung: Alfabeta.

Thomas, K. W. (2009). Instrinsic Motivation at Work: What Really DrivesEmployee Engagement. California: Barret-Koehler Publisher Inc.

Tomlinson, G. (2010). Building a culture of high employee engagement. Strategic HR Review, 9(3), 25-31. https://doi.org/10.1108/14754391011040046

Torang, S. (2012). Metode Riset Struktur \& Perilaku Organisasi. Bandung: Alfabeta.

Tufail, U., Ahmad, M. S., Ramayah, T., Jan, F. A., \& Shah, I. A. (2016). Impact of Islamic Work Ethics on Organisational Citizenship Behaviours among Female Academic Staff : the Mediating Role of Employee Engagement. Applied Research in Quality of Life. https://doi.org/10.1007/s11482-016-9484-5

Umam, K. (2010). Perilaku Organisasi. (P. Setia, Ed.). Bandung.

Wursanto. (2005). Dasar - Dasar Ilmu Organisasi. Yogyakarta: Andi Offset.

Yousef, D. A. (2000). Organizational Commitment as a Mediator of the Relationship between Islamic Work Ethic and Attitudes toward Organizational Change Organizational commitment as a Islamic work ethic and attitudes toward organizational change, 53(4), 513-537. https://doi.org/10.1177/0018726700534003 